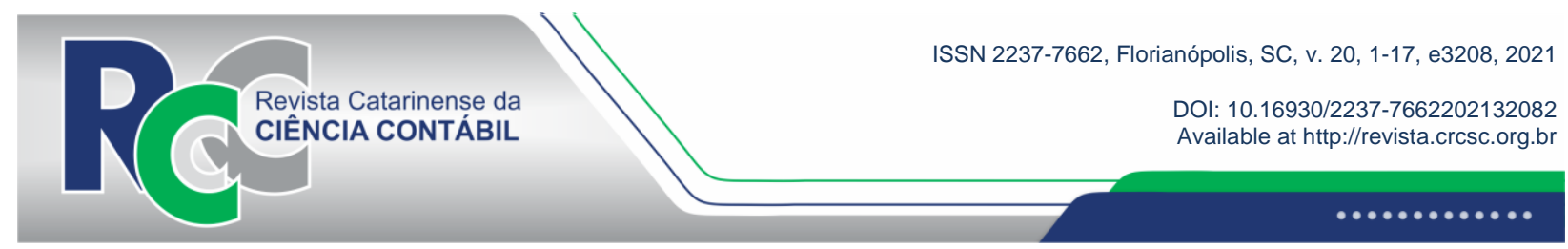

\title{
THE CONTRIBUTION OF STATE WEB PORTALS TO THE TRANSPARENCY OF THE VACCINATION PROCESS AGAINST COVID-19 IN BRAZIL
}

\author{
FABIANO MAURY RAUPP \\ Santa Catarina State University. Address: Av. Madre Benvenuta, 2037 | \\ Itacorubí| 88.035-001 | Florianópolis/SC | Brazil. \\ (D) http://orcid.org/0000-0001-9533-2574 \\ fabianoraupp@hotmail.com
}

\author{
ANA RITA SILVA SACRAMENTO \\ Federal University of Bahia. Address: Av. Reitor Miguel Calmon, $s / n \mid$ Vale \\ do Canela | 40.110-903 | Salvador/BA | Brazil. \\ (1) http://orcid.org/0000-0001-6739-5711 \\ anasacramento@ufba.br
}

\begin{abstract}
The article aimed to characterize the contribution of Brazilian state web portals to the transparency of the vaccination process against COVID-19. This research is descriptive, undertaken through a documentary study with a quali-quantitative approach. The purpose of the investigation comprises the web portals of the 26 Brazilian states and the Federal District. The study was guided by the application of the COVID-19 Vaccination Transparency Index (ITVC-19). The study data were obtained in six surveys carried out from the analysis of the portals, using content analysis as the processing technique. The constancy of some states at higher and lower levels (i.e., the extremes) and the evolution of others going from lower to higher levels was observed. Although the vast majority of web portals of Brazilian states contribute to the transparency of the vaccination against COVID-19, there are still states the portal of which, for being at opaque, low, or intermediary levels, seem to exist more due to a dominant technological imperative and less to favor the transparency of government actions. The study has a direct theoretical implication when it enables the development of an index that contributes to analyzing the transparency in the vaccination process against COVID-19. It is assumed that, in the future, the index may also be used for new studies on vaccination campaigns, not just this one restricted to the pandemic context. Consequently, it contributes to bridging the gap in the literature, notably the national literature. The practical contribution is also demonstrated by the provision of a diagnosis that, albeit specific, may be used by public managers interested in advancing vaccination transparency.
\end{abstract}

Keywords: Transparency. Vaccination. COVID-19.

Edited in Portuguese and English. Original version in Portuguese.

Received on 09/18/2021. Revised on 10/18/2021. Accepted on 10/29/2021, by Prof. Dr. Sérgio Murilo Petri (Editor-In-Chief) and Prof. Dr. Sandro Vieira Soares (Associate Editor). Published on 11/19/2021.

Copyright $(92021$ RCCC. All rights reserved The citation of article parts is allowed without prior authorization, provided the source is identified. 


\section{INTRODUCTION}

One of the loci chosen often by researchers interested in assessing transparency in Brazil has been web portals (Michener, Contreras, \& Niskier, 2018), a piece of modern information and communication technology capable of contributing to the implementation of transparency and, consequently, of accountability itself. The construction of transparency instruments such as portals "is a political process implemented in the context of the democratization of the country and the need for the political legitimization of the rulers" (Loureiro, Teixeira, \& Prado, 2008, p. 108). Although there is regulation for the compulsory requirement of using portals in this sense, it is assumed that transparency extrapolates the statutory requirements and must be appropriated in society as a fundamental value (Raupp \& Pinho, 2021).

To Raupp, Sacramento, Santos, and Pinho (2021), with the emergence of the COVID-19 pandemic and the consequent approval by surveillance agencies for the application of vaccines on an emergency basis, transparency became a condition to avoid that practices such as diversion, corruption, and clientelism appear in countries that, like Brazil, face structural problems. In this context, it is believed that the states, a government level in Brazil that must, among other functions, support the execution of national and municipal policies and that, a priori, technically have better conditions for constructing web portals, take on an important role for the production and diffusion of information related to the vaccination process within the scope of their territories. It remains to be known if the web portals of Brazilian states, the empirical object of this study that emerged due to the legislation (see Supplementary Law No. 131, 2009), contribute to the transparency of the vaccination against COVID-19.

The motivation for the study resides in the fact that transparency and COVID-19 are current themes of prominence in the calls for papers for publication within both the national and international scopes. Herein, these themes are analyzed together around their connections with a more recent phenomenon, the vaccination process against COVID-19, which is known to have begun in the world in December 2020 and, in Brazil, in January 2021. Such a phenomenon mobilizes policies related to epidemiological/health issues that, in turn, elicit the application of public resources. In the interim, Public Accounting has the ability to contribute to the availability of qualified information on the results obtained with such policies.

Given the exposed, this article aimed to characterize the contribution of Brazilian state web portals to the transparency of the vaccination process against COVID-19. For such, the following specific objectives were established: a) to apply the instrument to measure the COVID-19 Vaccination Transparency Index (ITVC-19) of these entities; b) to verify how the ITVC-19 is distributed throughout the country; c) to identify if there was an evolution in the transparency of the vaccination in the course of the surveys carried out.

The gap identified in the literature concerns research investigating the transparency of the vaccination process, captured through a survey on the Spell database in April 2021. The importance of the gap in theoretical and practical terms is justified because, as Santos and Mota (2020) recalled, most research on transparency focused on social regularity scenarios, with it being necessary to make efforts to assess how governments practice this phenomenon in situations of crises and uncertainty (Santos \& Mota, 2020). Also, it would not be an exaggeration to consider that, since transparency remains to be a challenge to be overcome in Brazil, the definition of a set of essential data and parameters for transparency may contribute to the standardization of the disclosure of data in the country during the pandemic, in the particular case of studying the vaccination process (OKBR, 2020).

This article contributes to bridging this gap when it dwells on the content of the state web portals to make inferences on the transparency of the vaccination against COVID-19. The study was guided by the application of the COVID-19 Vaccination Transparency Index (ITVC-19) and 
represents an extension of previous research (Raupp \& Pinho, 2020; Raupp et al., 2021). The study data were obtained in six surveys carried out from the analysis of the portals, using content analysis as the processing technique. Even though the majority of state web portals contribute to the transparency of the vaccination against COVID-19, there are still states the portal of which, for being at opaque, low, or intermediary levels, seem to exist more due to a technological imperative and less in favor of the transparency of government actions.

\section{LITERATURE REVIEW}

\subsection{Fragments of the evolution of the legislation on transparency in Brazil}

When it comes to transparency in Brazil in a broader sense, three legal landmarks were instituted to regulate provisions of the Federal Constitution of 1988: the Fiscal Responsibility Law (LRF), the Transparency Law, and the Access to Information Law (LAI). The LRF gave emphasis to transparency in fiscal management and defined instruments that should be considered for such (Supplementary Law No. 101, 2000). It is also necessary to mention that the said law already stated that broad dissemination should be given to such instruments, including in electronic means. The Transparency Law reinforced and amplified some provisions of the LRF; however, the focus on fiscal management remained. Article 48, sole paragraph, ensures the "release to the full knowledge and monitoring of society, in real-time, of detailed information on the budgetary and financial execution in electronic means of public access" (Supplementary Law No. 131, 2009). The LAI also reinforced provisions already contemplated in previous laws (LRV and the Transparency Law, for example); however, it significantly amplified the information to which transparency should be given, introduced a new transparency typology (passive transparency), and defined secrecy as an exception.

The previously mentioned laws and others not cited here could already, on their own, serve as bases for the disclosure of information on the vaccination process, given that it is a type of public information. Nevertheless, laws on transparency that emerged in the midst of the pandemic scenario must be brought to light. Among the emergency laws, one may mention Law No. $13979 / 2020$, in which $\S 2$ of article 4 determines that new contracts be made available immediately on official websites (Law No. 13979, 2020).

It should also be highlighted that, regarding the vaccination against COVID-19, the Brazilian Ministry of Health (MS) published a specific ordinance in the sense of favoring the transparency in this immunization process. GM/MS Ordinance No. 69 (2021), which instituted the compulsory requirement to record the application of the vaccines in the information systems of the Ministry of Health itself, requires, among other information, the identification of the batches and laboratories of the applied vaccine, the full name, sex, date of birth, and individual taxpayer identification number (CPF) or National Health Card number of the vaccinated person, and the type of dose applied. The need for editing a normative instrument of this nature in itself already indicates that one cannot yet state that there is in Brazil a "real commitment to transparency" (Michener et al., 2018, p. 613), but rather that this concept remains dependent on new formalizations for it to be implemented in the country, in both regular times and in times of calamities.

\subsection{Transparency as an element of accountability}

The term "transparency" is an integral part of the accountability concept, which, despite still lacking a direct translation to Portuguese, is known to contemplate others such as control, obligation to render accounts, justifications for actions that were undertaken or not, and rewards 
either in the form of premiums or punishment, among others (Pinho \& Sacramento, 2009). Considering the two-dimensionality that characterizes the accountability cycle proposed by Schedler (1999), transparency is specifically situated in the dimension that the author denominates answerability and has information and justification as attributes. Answerability is the accountability step that regards both the obligation for public agents to inform and provide detailed explanations on their acts and the right of the society to obtain such information and explanations with the details necessary for it to be able to judge them.

It should be underscored that, in Brazil, since the enactment of the Constitution of 1988, institutional changes have been implemented from the federal plane that favor the practice of this dimension and, therefore, the practice of transparency. For example, in the study developed by Sacramento and Pinho (2016), which outlined the timeline of this specific dimension until 2014, the researchers characterized the trajectory of answerability in Brazil as continuous and incrementally developed. The authors pointed out that, since its origin, issues of financial and budgetary nature motivate this trajectory and admitted that only recently did other more profound matters of democracy - e.g., the establishment of the National Truth Commission that sought to determine Human Rights violations during the military period - begin to motivate the pursuance of the trajectory of answerability in the country (Pinho \& Sacramento, 2009).

Therefore, one may infer that transparency is a "necessary condition, albeit not sufficient, for the implementation of any democratic order, insofar as there is only effective control of the rulers if their acts are properly informed to society" (Loureiro et al., 2008, p. 108). Hence, the "real commitment to transparency, after all, represents the provision of sufficient information to render governments susceptible to criticism" (Michener et al., 2018, p. 613).

It is known that transparency is a phenomenon studied from various prisms, including that which takes into account who started the initiative for the action (Zuccolotto, Teixeira, \& Riccio, 2015), designated by active transparency. Such a typology refers to making information available by the initiative of the different government entities, voluntary and/or stemming from statutory requirements (Supplementary Law No. 101, 2000; Supplementary Law No. 131, 2009; Law No. 12527, 2011), commonly conveyed by the web portal of the entity itself. It must be highlighted that Federal Law No. 12527, known as the Access to Information Law (LAI), defines information as "data, processed or not, that may be used to produce and transmit knowledge, contained in any mean, support, or format" (Law No. 12527, 2011).

Moreover, stimulus already exists for the implementation of the open data policy in Brazil. Federal Decree No. 8777 of May 11, 2016, which instituted the open data policy of the Federal Executive Branch, established, among its objectives, that of promoting the publication of data contained in databases of agencies and entities of the Federal Public Administration, direct, autarchic, and foundational, and improve the public transparency culture (Decree No. 8777, 2016). According to the mentioned decree, open data is understood as those "accessible to the public, represented in digital means, structured in an open format, processable by machines, referenced on the Internet, and made available under an open license that allows it free use, consumption, or cross-linking, limited to crediting the authorship or source" (Decree No. 8777, 2016).

\subsection{Transparency in a time of crisis}

It is deduced that there is no lack of formal institutional mechanisms for practicing transparency within the scope of the public administration in Brazil. However, research specifically on government transparency regarding the actions related to the COVID-19 pandemic indicates that one cannot admit the term as having been absorbed by the Brazilian political culture in general, although advances in this sense are recognized. Such research includes the study by Machado et al. (2020), who, upon investigating if the measures that eased deadlines and procedures for fulfilling requests for information in the pandemic period had a significant impact on 
subnational governments, concluded that the right to access to public information is fragile and permanently tensioned in the country. In another study, Pinho et al. (2020) found non-compliance with the statutory requirements of transparency of the data on the provision of essential and desirable information on the emergency contracts for tackling COVID-19 in some capital municipalities surveyed.

Raupp and Pinho (2020, p. 3725) analyzed the construction of transparency about COVID19 by the Brazilian states and, "even if the data may reveal a concern of some governments with building better conditions for making information on the new coronavirus available", understood that "the states must still evolve in information transparency". To the authors, "the question remains in the air if this episode could transform into a turning point in the commitment of governments, restricted here to the state governments, and the mobilization of society for the construction of more effective transparency" (Idem, p. 3736). The authors stressed the need for future research both within and outside the COVID-19 scope, which reinforces the findings by Santos and Mota (2020) that, upon promoting reflections about issues already evident surrounding how government transparency has developed in the current conjecture, concluded that the context is challenging for the academic community specialized on the theme. These authors understood that there are provocative questions that need the attention of researchers to advance the understanding of this type of phenomenon.

To Raupp et al. (2021, p. 15), who characterized the practice of active transparency in the Brazilian capitals in the vaccination against COVID-19, a study considered unprecedented within the national scope, the government entities "spent the last months adapting their portals so they could make information on COVID-19 available, from epidemiological matters to emergency contracts". The authors assumed that an adaptation for information on vaccination had occurred and/or been more effective, a fact that ended up not being confirmed. "Hence, what seems to really be lacking is transparency as a value consolidated in the Brazilian reality, and that may be partly explained by more structural issues of the Brazilian context" (Idem, p. 15).

As one may observe, the emergency of the pandemic evoked specific studies on the transparency of various acts practiced by the public power. However, since a gap regarding the direct contribution of state web portals to the transparency of the vaccination process is notorious, this study intends to contribute to bridging it.

\section{METHOD}

This research is descriptive, undertaken through a documentary study with a qualiquantitative approach. The purpose of the investigation comprises the web portals of the 26 Brazilian states and the Federal District. Such a choice is justified under different prisms. First, due to the fact that they intermediate the distribution of vaccines to the municipalities coming from the Federal Government, having a fundamental role in this direction. Second, for understanding that, compared to the municipalities, the states tend to present better financial and/or technical conditions to present more structured portals in terms of transparency requirements, even contributing to the construction of accountability. Lastly, and still compared to the municipalities, the states are more distant from the population, and it is assumed that the information and communication technologies may at least partially bridge the absence of this in-person contact.

The study was guided by the application of the COVID-19 Vaccination Transparency Index (ITVC-19), the dimensions, criteria, and respective scores of which are presented in Figure 1.

\begin{tabular}{|c|l|l|l|}
\hline Dimension & Criterion & \multicolumn{1}{c|}{ Description } & \multicolumn{1}{c|}{ Score } \\
\hline \multirow{2}{*}{ Content } & Available & $\begin{array}{l}\text { Number of doses the } \\
\text { state/municipality has }\end{array}$ & $\begin{array}{l}0=\text { does not present; } \\
1=\text { presents. }\end{array}$ \\
\hline
\end{tabular}




\begin{tabular}{|c|c|c|c|}
\hline & $\begin{array}{l}\text { Age or Age } \\
\text { Range }\end{array}$ & Applied doses by age or age range & $\begin{array}{l}0=\text { does not present; } \\
0.5=\text { presents an overall average; } \\
1=\text { presents age or age range. }\end{array}$ \\
\hline & Sex & Applied doses by sex & $\begin{array}{l}0=\text { does not present; } \\
0.5=\text { presents an overall average; } \\
1=\text { presents sex. }\end{array}$ \\
\hline & $\begin{array}{l}\text { Target } \\
\text { population }\end{array}$ & Applied doses by target population & $\begin{array}{l}0=\text { does not present; } \\
0.5=\text { presents an overall average; } \\
1=\text { presents. }\end{array}$ \\
\hline & Dose type & $\begin{array}{l}\text { Applied doses by first and second } \\
\text { doses }\end{array}$ & $\begin{array}{l}0=\text { does not present } \\
1=\text { presents }\end{array}$ \\
\hline & Vaccine type & Applied doses by vaccine type & $\begin{array}{l}0=\text { does not present } \\
1=\text { presents }\end{array}$ \\
\hline Granularity & Location & $\begin{array}{l}\text { Geographical aggregation level of the } \\
\text { applied doses (by municipality, by } \\
\text { health establishment, etc.) }\end{array}$ & $\begin{array}{l}0=\text { does not present } \\
1=\text { presents }\end{array}$ \\
\hline \multirow{3}{*}{ Format } & Visualization & $\begin{array}{l}\text { Panel for consultation by the general } \\
\text { public }\end{array}$ & $\begin{array}{l}0=\text { does not present; } \\
0.5=\text { presents a bulletin and/or news } \\
\text { articles; } \\
1=\text { presents a panel. }\end{array}$ \\
\hline & Open format & $\begin{array}{l}\text { Data structured in at least one } \\
\text { spreadsheet in editable format, } \\
\text { preferably open (CSV, ODS) }\end{array}$ & $\begin{array}{l}0=\text { does not present; } \\
1=\text { presents. }\end{array}$ \\
\hline & $\begin{array}{l}\text { Historical } \\
\text { series }\end{array}$ & $\begin{array}{l}\text { Single updated database with the } \\
\text { entire history, since the beginning of } \\
\text { the application }\end{array}$ & $\begin{array}{l}0=\text { does not present } \\
1=\text { presents }\end{array}$ \\
\hline
\end{tabular}

Figure 1. Analysis model

Source: Raupp et al. (2021, p. 6-7).

The Content dimension considers "parameters that may aid the production of more in-depth analyses on the dissemination of the new coronavirus throughout the country. Each indicator receives a Weight of 1 in the Index composition" (OKBR, 2020, p. 6). Granularity "is the dimension that assesses the detailing of the data disclosed by the authorities, providing an extra information layer. Each indicator receives a Weight of 3 in the Index composition" (OKBR, 2020, p. 14). In turn, the Format assesses "how the data were made available. The way of accessing, reading, and sharing the data is a determinant of their analysis potential. Each indicator receives a Weight of 5 in the Index composition" (OKBR, 2020, p. 15). The dimensions are qualitative and quantitative; for example, the 'available doses' criterion is quantitative, whereas the 'visualization' criterion is qualitative.

According to Raupp et al. (2021), the first version of the ITVC-BR was based on the COVID-19 Transparency Index (ITC-19) devised by Open Knowledge Brazil (OKBR). With the first version of the index, a pretest was carried out with the Brazilian capitals, in which necessary adjustments were identified, resulting in the second and most current version of the ITVC-BR. The index adopted the scale from 0 to 100 of the ITC-19 (OKBR, 2020), in which 0 is attributed to the least transparent state and 100 to the most transparent. The transparency levels were defined from the following score intervals: opaque (0 to 19), low (20 to 39), intermediate (40 to 59), good (60 to 79 ), and high (80 to 100$)$.

The study data were obtained in six surveys carried out from the analysis of the portals on April 30, May 7, 14, 21, and 28, and June 4, 2021, besides communication by email with the states. Three steps were carried out in each survey, always in the same sequence: data collection on the portals; preliminary calculation of the ITVC-19 and submission to the states for checking; data analysis. We emphasize that the adoption of the ITVC-BR by the states was not compulsory.

The collections were always carried out on Fridays, and, right after being finalized, the 
results were submitted to the communication sectors of the states so they could check. The interval between the submission date and the eve of the following collection was considered the response time. Although the states did not identify divergences in their checking, advancements by some entities were perceived in later collections in the sense of seeking to meet the criteria of the ITVC$\mathrm{BR}$. The data considered for analysis were those obtained after the checking of the communication sectors of the states.

The data were collected directly on the state web portals through an observation protocol, the sections of which are described in Figure 2. The observation protocol was based on the analysis model and had the purpose of guiding the data collection process to enable the investigation of the dimensions and its respective criteria used to make inferences on the transparency of the vaccination against COVID-19.

\begin{tabular}{|l|l|}
\hline \multicolumn{1}{|c|}{ State } & \multicolumn{1}{c|}{ Main collection section } \\
\hline Acre & http://covid19.ac.gov.br/vacina/inicio \\
\hline Alagoas & https://www.saude.al.gov.br/vacinacao-contra-a-covid-19/ \\
\hline Amapá & http://painel.corona.ap.gov.br/vacina/ \\
\hline Amazonas & https://www.fvs.am.gov.br/indicadorSalaSituacao_view/75/2 \\
\hline Bahia & https://bi.saude.ba.gov.br/vacinacao/ \\
\hline Ceará & https://coronavirus.ceara.gov.br/servicos/vacina// \\
\hline Federal District & http://www.saude.df.gov.br/vacinometro/ \\
\hline Espírito Santo & https://coronavirus.es.gov.br/painel-vacinacao \\
\hline Goiás & encurtador.com.br/IKOV7 \\
\hline Maranhão & https://painel-covid19.saude.ma.gov.br/vacinas \\
\hline Mato Grosso & http://www.saude.mt.gov.br/paineldistribuicaovacinasmt// \\
\hline Mato Grosso do Sul & encurtador.com.br/mpDNX \\
\hline Minas Gerais & https://coronavirus.saude.mg.gov.br/vacinometro \\
\hline Pará & https://www.saude.pa.gov.br/vacinometro/ \\
\hline Paraíba & https://paraiba.pb.gov.br/diretas/saude/coronavirus/painel-de-vacinacao \\
\hline Paraná & http://www.coronavirus.pr.gov.br/vacinacao-ranking \\
\hline Pernambuco & encurtador.com.br/beKM8 \\
\hline Piauí & encurtador.com.br/chwV9 \\
\hline Rio de Janeiro & https://vacinacaocovid19.saude.rj.gov.br/vacinometro \\
\hline Rio Grande do Norte & https://rnmaisvacina.lais.ufrn.br/transparencia/vacinacao/ \\
\hline Rio Grande do Sul & https://vacina.saude.rs.gov.br/ \\
\hline Rondônia & https://covid19.sesau.ro.gov.br/Home/Vacina \\
\hline Roraima & https://saude.rr.gov.br/vacinometro/ \\
\hline Santa Catarina & https://www.coronavirus.sc.gov.br/vacinacao/ \\
\hline São Paulo & https://vacinaja.sp.gov.br/vacinometro/ \\
\hline Sergipe & https://todoscontraocorona.net.br/inicial-vacinas/ \\
\hline Tocantins & http://integra.saude.to.gov.br/covid19/Vacinometro \\
\hline
\end{tabular}

Figure 2. Data collection section

Source: Study data (2021).

The collections were always carried out on Fridays, with weekly intervals, and considered information made available over the week. After each collection, the results were submitted to the communication sector of each state so they could check them and indicate any incoherence in the collection if necessary, or even refer the checking to a more appropriate sector for such. The last step of the study consisted of analyzing the data using the content analysis technique, and the results and discussions are presented in the next section. 


\section{RESULTS}

Initially, the results are presented per survey carried out, emphasizing the score, level, and position of the states, as one may observe in Table 1. The score column stems from the individualized scores of the criteria in each of the dimensions, as per the weights identified in the method section. As a consequence of the score, we arrived at the level and position columns. 
Table 1

Score, level, and position of the States in the surveys carried out

\begin{tabular}{|c|c|c|c|c|c|c|c|c|c|c|c|c|c|c|c|c|c|c|c|c|c|c|c|}
\hline \multicolumn{4}{|c|}{ 1st survey } & \multicolumn{4}{|c|}{ 2nd survey } & \multicolumn{4}{|c|}{ 3rd survey } & \multicolumn{4}{|c|}{ 4th survey } & \multicolumn{4}{|c|}{ 5th survey } & \multicolumn{4}{|c|}{ 6th survey } \\
\hline 䔍 & 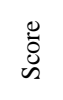 & 岕 & 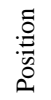 & 焉 & 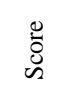 & बे & $\begin{array}{l}\tilde{0} \\
: 0 \\
: 0 \\
0 \\
0\end{array}$ & 意 & 总 & 岕 & $\begin{array}{l}\text { : } \\
: 0 \\
0 \\
0\end{array}$ & 莺 & 苛 & ग्ञ & $\begin{array}{l}\text { : } \\
: 0 \\
0 \\
0\end{array}$ & 莺 & 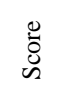 & गे & $\begin{array}{l}\text { : } \\
: 0 \\
0 \\
0 \\
0\end{array}$ & 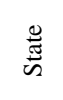 & 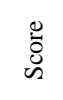 & ब्ग & $\begin{array}{l}\text { : } \\
: 0 \\
0 \\
0\end{array}$ \\
\hline SP & 100 & High & 1 & $\mathrm{AC}$ & 100 & High & 1 & $\mathrm{AC}$ & 100 & High & 1 & $\mathrm{AC}$ & 100 & High & 1 & $\mathrm{AC}$ & 100 & High & 1 & $\mathrm{AC}$ & 100 & High & 1 \\
\hline $\mathrm{AC}$ & 96 & High & 2 & RS & 100 & High & 1 & RS & 100 & High & 1 & RS & 100 & High & 1 & RS & 100 & High & 1 & RS & 100 & High & 1 \\
\hline $\mathrm{BA}$ & 92 & High & 3 & TO & 96 & High & 2 & MG & 96 & High & 2 & $\mathrm{GO}$ & 96 & High & 2 & $\mathrm{GO}$ & 96 & High & 2 & RO & 98 & High & 2 \\
\hline TO & 92 & High & 3 & BA & 92 & High & 3 & TO & 96 & High & 2 & MG & 96 & High & 2 & MG & 96 & High & 2 & GO & 96 & High & 3 \\
\hline RS & 90 & High & 4 & GO & 92 & High & 3 & BA & 92 & High & 3 & $\mathrm{TO}$ & 96 & High & 2 & $\mathrm{TO}$ & 96 & High & 2 & MA & 96 & High & 3 \\
\hline MG & 88 & High & 5 & MG & 88 & High & 4 & $\mathrm{GO}$ & 92 & High & 3 & BA & 92 & High & 3 & BA & 92 & High & 3 & MG & 96 & High & 3 \\
\hline $\mathrm{GO}$ & 71 & Good & 6 & SP & 88 & High & 4 & SP & 92 & High & 3 & SP & 92 & High & 3 & SP & 92 & High & 3 & TO & 96 & High & 3 \\
\hline $\mathrm{RN}$ & 71 & Good & 6 & DF & 79 & Good & 5 & $\mathrm{RR}$ & 75 & Good & 4 & DF & 77 & Good & 4 & $\mathrm{RR}$ & 79 & Good & 4 & BA & 92 & High & 4 \\
\hline $\mathrm{RR}$ & 71 & Good & 6 & $\mathrm{RN}$ & 75 & Good & 6 & DF & 73 & Good & 5 & $\mathrm{RO}$ & 75 & Good & 5 & DF & 77 & Good & 5 & SP & 92 & High & 4 \\
\hline ES & 67 & Good & 7 & RO & 75 & Good & 6 & PR & 71 & Good & 6 & PR & 71 & Good & 6 & MS & 75 & Good & 6 & AP & 79 & Good & 5 \\
\hline MS & 67 & Good & 7 & ES & 71 & Good & 7 & PI & 71 & Good & 6 & PI & 71 & Good & 6 & PR & 71 & Good & 7 & ES & 79 & Good & 5 \\
\hline PI & 67 & Good & 7 & PR & 71 & Good & 7 & RO & 71 & Good & 6 & $\mathrm{RN}$ & 71 & Good & 6 & PI & 71 & Good & 7 & $\mathrm{RR}$ & 79 & Good & 5 \\
\hline SE & 67 & Good & 7 & PI & $\begin{array}{ll}71 \\
\end{array}$ & Good & 7 & SE & 71 & Good & 6 & $\mathrm{RO}$ & 71 & Good & 6 & $\mathrm{RN}$ & 71 & Good & 7 & DF & $\begin{array}{ll}77 \\
\end{array}$ & Good & 6 \\
\hline $\mathrm{AM}$ & 50 & Intermediate & 8 & RR & 71 & Good & 7 & $\mathrm{RN}$ & 67 & Good & 7 & $\mathrm{SE}$ & 71 & Good & 6 & $\mathrm{RO}$ & 71 & Good & 7 & MS & 75 & Good & 7 \\
\hline DF & 50 & Intermediate & 8 & SE & 67 & Good & 8 & MS & 50 & Intermediate & 8 & MS & 67 & Good & 7 & $\mathrm{SE}$ & 71 & Good & 7 & SE & 75 & Good & 7 \\
\hline $\mathrm{RO}$ & 50 & Intermediate & 8 & AP & 54 & Intermediate & 9 & PA & 50 & Intermediate & 8 & MA & 54 & Intermediate & 8 & MA & 54 & Intermediate & 8 & PR & 71 & Good & 8 \\
\hline MA & 46 & Intermediate & 9 & AM & 54 & Intermediate & 9 & RJ & 50 & Intermediate & 8 & PA & 50 & Intermediate & 9 & PA & 50 & Intermediate & 9 & PI & 71 & Good & 8 \\
\hline $\mathrm{RJ}$ & 46 & Intermediate & 9 & MA & 50 & Intermediate & 10 & SC & 50 & Intermediate & 8 & $\mathrm{RJ}$ & 50 & Intermediate & 9 & $\mathrm{RJ}$ & 50 & Intermediate & 9 & $\mathrm{RN}$ & 71 & Good & 8 \\
\hline $\mathrm{AP}$ & 42 & Intermediate & 10 & MS & 50 & Intermediate & 10 & ES & 46 & Intermediate & 9 & $\mathrm{SC}$ & 50 & Intermediate & 9 & $\mathrm{SC}$ & 50 & Intermediate & 9 & $\mathrm{SC}$ & 71 & Good & 8 \\
\hline PA & 42 & Intermediate & 10 & $\mathrm{SC}$ & 50 & Intermediate & 10 & MA & 46 & Intermediate & 9 & ES & 46 & Intermediate & 10 & ES & 46 & Intermediate & 10 & $\mathrm{CE}$ & 50 & Intermediate & 9 \\
\hline MT & 38 & Low & 11 & PA & 46 & Intermediate & 11 & MT & 42 & Intermediate & 10 & MT & 42 & Intermediate & 11 & $\mathrm{CE}$ & 42 & Intermediate & 11 & PA & 50 & Intermediate & 9 \\
\hline PR & 29 & Low & 12 & RJ & 46 & Intermediate & 11 & PB & 29 & Low & 11 & PB & 29 & Low & 12 & MT & 42 & Intermediate & 11 & RJ & 50 & Intermediate & 9 \\
\hline $\mathrm{PE}$ & 29 & Low & 12 & MT & 42 & Intermediate & 12 & AP & 21 & Low & 12 & $\mathrm{CE}$ & 25 & Low & 13 & PB & 29 & Low & 12 & MT & 42 & Intermediate & 10 \\
\hline $\mathrm{PB}$ & 25 & Low & 13 & PB & 29 & Low & 13 & $\mathrm{AM}$ & 21 & Low & 12 & $\mathrm{PE}$ & 25 & Low & 13 & $\mathrm{PE}$ & 25 & Low & 13 & $\mathrm{~PB}$ & 29 & Low & 11 \\
\hline SC & 25 & Low & 13 & $\mathrm{AL}$ & 25 & Low & 14 & PE & 17 & Opaque & 13 & $\mathrm{AP}$ & 21 & Low & 14 & $\mathrm{AP}$ & 21 & Low & 14 & PE & 25 & Low & 12 \\
\hline $\mathrm{CE}$ & 21 & Low & 14 & $\mathrm{CE}$ & 21 & Low & 15 & $\mathrm{AL}$ & 4 & Opaque & 14 & AM & 21 & Low & 14 & $\mathrm{AM}$ & 21 & Low & 14 & AM & 21 & Low & 13 \\
\hline $\mathrm{AL}$ & 0 & Opaque & 15 & PE & 13 & Opaque & 16 & $\mathrm{CE}$ & 0 & Opaque & 15 & $\mathrm{AL}$ & 4 & Opaque & 15 & $\mathrm{AL}$ & 4 & Opaque & 15 & $\mathrm{AL}$ & 4 & Opaque & 14 \\
\hline
\end{tabular}

Source: Study data (2021). 
In this first survey, carried out on April 30, 2021, only six states (22.22\%) were at the ideal transparency level, i.e., the high level, with the state of São Paulo being in the first place. One may say that the good level is also a satisfactory transparency condition, and it was identified in seven other states $(25.92 \%)$. If the states with high, good, and intermediate levels are added (states with a condition close to good), it is possible to state that the set of investigated entities are not far from the desirable situation of transparency in the vaccination process against COVID-19. On the other hand, one must score those that are at lower levels (low and opaque), which together represent seven states $(25.92 \%)$.

In the individualized analysis, the criteria of available doses and sex were the least met. These data drew attention, especially relative to the sex criterion, given that the National Operationalization Plan for the Vaccination against COVID-19 (Law No. 13979, 2020) itself defined that the data regarding the number of applied doses per state and municipality in a given period would be made available to the general public by sex, age range, and vaccine type. At the other end, the items most complied with were the target population, dose type, location, and visualization.

One must observe that the first survey took place three months after the beginning of the vaccination in Brazil on January 17, when the first person vaccinated in Brazil received the first dose of CoronaVac. Even understanding that the results could be more encouraging, it is necessary to stress that the states were not prepared (human, financial, and technological resources) to meet the transparency process in the vaccination. On the other hand, one may also assume that, from the technical viewpoint, this adjustment would not have been so hard, given that they had already been working with the transparency on the broader health/epidemiological issue of COVID-19. A proof of this is the fact that the states well-ranked in this first survey (Acre, Goiás, and Rio Grande do Sul) even presented data on the applied doses by race/skin color, i.e., an item beyond those contained in the analysis model.

From the second survey, carried out on May 7, 2021, we began to consider the available doses criterion as met if the state provided data on the vaccines received and applied or on the doses distributed and doses applied. Some states even presented information beyond the expected, as occurred with the state of Acre, which presented an exclusive section for information on vaccines received, with data on numbers, values, batches, and manufacturers, made available by date of receipt. Considering the information on available vaccines, Acre reached the maximum score. There was also a specific section for the distributed vaccines, which brought data by regional health offices and municipal health secretariats, the information on which is also provided daily. On the other hand, the bulletins on the vaccination remained outdated, which leads one to believe they may have been abandoned because the information was being made available on the panel.

In some states, the provision of data on the percentage of people vaccinated was observed. The states of Amapá and Amazonas, for example, presented the percentage of people vaccinated by first and second doses applied. Relative to the state of Amazonas, despite the possibility of downloading the data in an open format, this indicator was not scored because the information available in this format is minimal. Indeed, this is a characteristic, i.e., those who presented the possibility of an open format ended up presenting a negligible dataset, usually inferior to that available on the panel itself. In turn, in the state of Maranhão, the open format was disregarded because the information was outdated.

In this survey, seven states $(25.92 \%)$ received a high transparency level, with the states of Acre and Rio Grande do Sul sharing first place with the maximum score. In turn, the good level was observed for eight states (29.62\%). When the number of states with high, good, and intermediate levels is added, this data went from 20 states $(74.07 \%)$ in the first survey to 23 states $(85.18 \%)$ in the second survey. Consequently, a reduction in the number of states at the low transparency level was identified, going from six states $(22.22 \%)$ in the first survey to three 
$(11.11 \%)$ in the second. In the individualized analysis, the available doses criterion became part of the set of items complied with the most, along with the target population, dose type, location, and visualization. The sex criterion remained in the category of those least met.

In the third survey, carried out on May 14, 2021, it was noticed that the states of Alagoas, Ceará, Paraíba, and Pernambuco remained at the lower levels (low and opaque) in the first three surveys. For example, the immunization bulletin was considered a source of information for the state of Alagoas, with the type of dose applied being the only datum required for the index that was identified. Similarly, Ceará maintained a website with minimal information on vaccination. Another characteristic made evident in this survey was the absence of an update date for the information on some portals. The states of Amapá and Amazonas made several pieces of information available, but the update date was not found. For these two portals, the only datum considered was the existence of a panel with information, which meets the visualization criterion.

The same seven states (25.92\%) at the high transparency level in the second survey remained as such in the third survey, albeit with some different positions. Relative to the good level, the state of Espírito Santo left this level and began to integrate the set of states at the intermediate transparency level, given that it was identified that most of the information made available by this state referred to the doses distributed and not the doses applied, which is the focus of most of the criteria of the content dimension. The intermediate level also had a reduction in the total number of states at this level compared to the second survey. The reduction in the number of states with good and intermediate levels consequently opened space or increases to be identified at the lower levels (low and opaque), then with three states (11.11\%) each. In the microanalysis, the sex criterion remained the least met, while available doses, dose type, location, and visualization were the criteria with the highest number of occurrences in the states.

In the fourth survey, carried out on May 21, 2021, it was found that the same seven states (25.92\%) of the previous surveys remained at the high transparency level. Relative to the good level, the novelty was the integration of the state of Mato Grosso do Sul, which left the intermediate level because it started to indicate the age range of its vaccinated people. Therefore, the good level then included eight entities and the intermediate level, six, the same six as the third survey (PA, RJ, SC, ES, MA, and MT). Regarding the low level, an increase of two entities was observed, namely $\mathrm{CE}$, which began to provide the available doses, and PE, which began to indicate the municipality of the vaccinated people, leading the low level to then include five states. With this, the opaque level became exclusive to the state of Alagoas since it only provides a "distribution note", with the last one being dated from May 4 and was worded with verbs in the future (e.g., "All CoronaVac doses will be destined to..."; "Hence, 7620 doses (D1) will be distributed for the conclusion of this priority group"), which does not allow us to make inferences on its materialization.

Concerning the findings of the fifth survey, carried out on May 28, we have that the same seven states of the previous surveys remained at the high level, all with the same score verified in the fourth survey (AC, RS, MG, TO, BA, GO, and SP). The same situation was found at the good level regarding the number of entities (eight), with RR, DF, and MF positively changing their scores since RR and DF began providing information on the sex criterion of the vaccinated people and MS the historical series in the date format. Regarding the other levels, it was observed that the intermediate level then included seven states since Ceará began to inform the location of the vaccinated people, a fact that led it to leave the low level. The other states remained with the same scores; therefore, their positions in the ITVC-19 scale did not change: PB, PE, AP, and AM at the low level and AL alone at the opaque level. It was determined in the microanalysis that the sex criterion remained the least met, although two additional states began providing this information. In turn, the criteria of available doses, dose type, location, and visualization remained with the 
highest number of occurrences in the states.

It should be emphasized that, among the emails sent to the entities studied in this survey, two of them responded bringing information to the researchers, Rondônia and Santa Catarina, with Rondônia informing that "the data system that provides transparency to the vaccination carried out in the state of Rondonia is in an adjustment phase that may contemplate the requests mentioned in the study". In turn, Santa Catarina informed that it "on May 31, it launched its Vaccine Meter (Vacinômetro), an interactive panel on which it is possible to consult in real-time the information on the doses of the vaccine against COVID-19 applied in Santa Catarina".

The sixth survey was carried out on June 6, when the entry of two other states at the high level was observed: Rondônia and Maranhão, which up to the fifth survey were at the good and intermediate levels, respectively. Hence, the high level then included nine states: RO, MA, AC, RS, MG, TO, BA, GO, and SP. It should be emphasized that the entry of Rondônia at this level was the consequence of the state providing information on sex, vaccine type, and historical series of the vaccinated people, meeting that stated in the email sent to the researchers. In turn, Maranhão began providing open data and informing the historical series of those vaccinated.

Two entities entered the good level, Amapá and Espírito Santo, leading this level to include the most entities: ten (AP, DF, ES, MS, PR, PI, RN, RR, SC, and SE). The entry of Amapá at this level was a consequence of the state making available a spreadsheet with open data containing the indicators required for the ITVC-19. However, it was found that the last modification to this spreadsheet had occurred on May 31, which already configures some delay in the provision of the data. In turn, the entry of the state of Espírito Santo stemmed from the fact that, in this survey, the only indicator not located on its panel was the historical series. Another advancement verified was the creation of the Vaccine Meter of Santa Catarina, also confirming the information contained in the response given to the email sent by the researchers.

Regarding the other levels, it was observed that the intermediate level included then only four entities since ES and SC passed to the good level and MA to the high level. Hence, the following states remained at the intermediate level: CE, MT, PA, and RJ. The number of entities at the low level decreased as well because, as already asserted, the state of Amapá began integrating the good level, with only PB, PE, and AM remaining at the low level. In turn, AL conserved its performance, remaining alone at the opaque level. It was determined in the microanalysis that the sex criterion remained the least met, followed by the criteria of vaccine type, open format, and historical series.

\section{DISCUSSIONS}

Considering that the sixth survey contemplated the last and most current diagnosis on the transparency of the states in the vaccination process, we sought to discuss its results more closely. For such, Figure 3 is initially presented, showing a map of the transparency of the vaccination data for the states - ITVC-19 synthesizes the obtained data. 


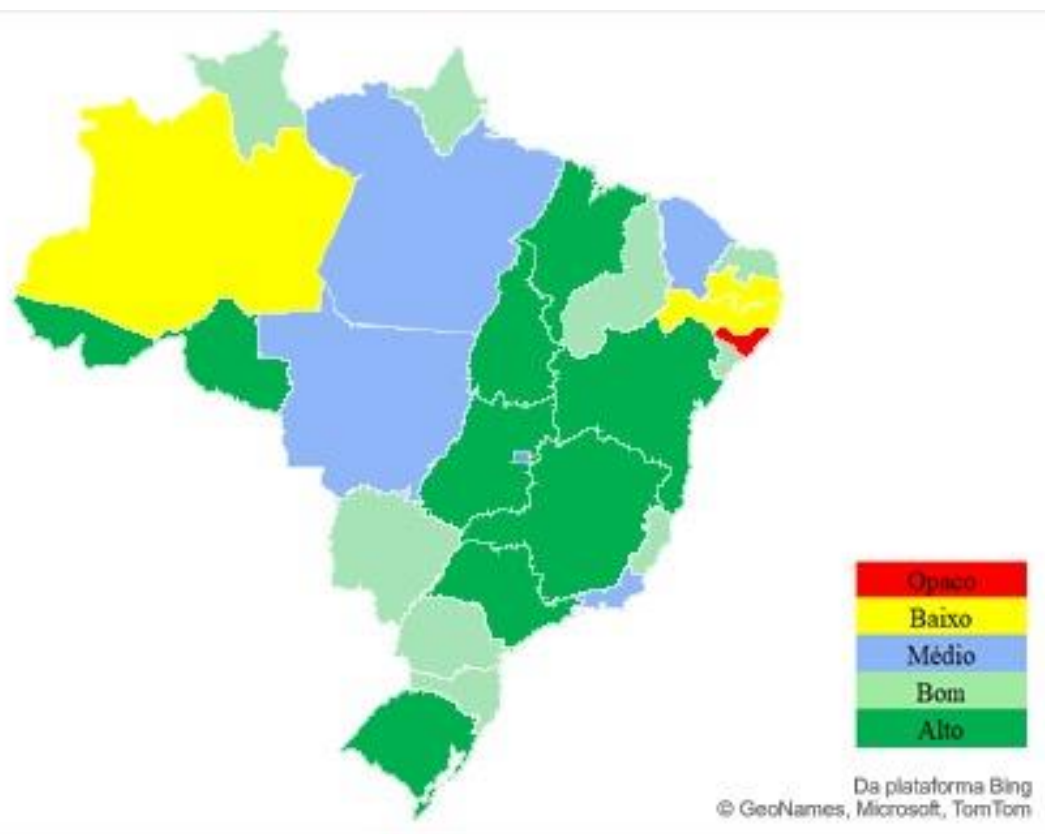

Figure 3. Transparency of the vaccination data for the states - ITVC-19 (sixth survey) Source: Study data (2021).

As one may observe in Figure 3, upon the closing of this study, all ITVC-19 levels were identified in the country, being distributed by the regions as follows: the opaque level was only verified in the Northeast Region (AL); the low level, in the Northeast (PE and PB) and North $(\mathrm{AM})$; the intermediate level, in the Northeast (CE), Central-West (MT), North (PA), and Southeast (RJ); the good level, in the Northeast (PI, RN, and SE), Central-West (DF and MS), North (AP and RR), Southeast (ES), and South (PR and SC); the high level, in the Northeast (MA and BA), Central-West (TO and GO), North (RO and AC), Southeast (MG and SP), and South (RS). The most positive distinctions were Acre and Rio Grande do Sul, which obtained the maximum score (100) from the second to the sixth surveys; Alagoas stood out negatively since it figured at the low level in one of the surveys and at the opaque level in the other five. This scenario, in which only two states obtained the maximum score for the ITVC-19, agrees with the findings by Pinho et al. (2020) because it made evident that transparency is a challenge for the country, given that the desirable data about the transparency process of the vaccination in the country were not available and/or open to the public.

This is a context in which the absence of commitment to transparency prevents the provision of information capable of making the states susceptible to criticism regarding the transparency of the vaccination process against COVID-19 (Michener et al., 2018). The results conform to those obtained by Machado et al. (2020), who also concluded that access to public information is fragile and constantly tensioned in the country. Although the empirical object is different, the study by Machado et al. (2020) also addressed transparency in a pandemic period.

Throughout the six surveys carried out, advances by the states were observed, with states even leaving lower levels for levels with satisfactory compliance with the transparency requirements about the vaccination process. These results are backed by Raupp and Pinho (2020, p. 3736), to whom "the advances detected in this short and tense period may serve as a basis to consider the transparency issue in Brazil from a more structural viewpoint". The responses resemble those obtained by Raupp and Pinho (2020), i.e., so far positive, with the sixth survey completed. It is also opportune to present that, according to Raupp and Pinho (2020, p. 3736- 
3737), "such a fact may be due to the magnitude and implications that the pandemic has, affecting virtually the entire population, which mobilized governments to give swift responses to society".

The fact that the survey began in April 2021, following and complementing the study by Raupp and Pinho (2020), and over a year after the pandemic was declared in Brazil, merits a reflection. After all this time, the states still did not disclose all information on the web portals. Even after one year had passed, some states remained at lower levels relative to the transparency of the vaccination. The results also corroborated the findings by Raupp et al. (2021) because there were still states with outdated information, information fragmented in different sections of the portals, and an absence of standardization in the form of conveying the information, which may be through news articles, reports, epidemiological bulletins, and/or panels.

In this case, the results with the transparency in the vaccination may also make evident the extent to which the states are accountable in this sense (Pinho \& Sacramento, 2009), with indications that they need to evolve in terms of answerability (Schedler, 1999), which reinforces the idea that, in Brazil, the trajectory of this dimension is continuous and developed incrementally (Sacramento \& Pinho, 2016). It is not excessive to recall that "this may be due to the situation of 'war' that the health system had been facing, a challenge never observed before" (Raupp \& Pinho, 2020, p. 3736).

\section{CONCLUSIONS, CONTRIBUTIONS, AND FUTURE STUDIES}

The article aimed to characterize the contribution of Brazilian state web portals to the transparency of the vaccination process against COVID-19. The COVID-19 Vaccination Transparency Index (ITVC-19) measurement instrument was applied in six weekly surveys from April to June 2021 to verify how the index was distributed throughout the country and identify possible evolutions in the transparency of the vaccination over the surveys carried out. The constancy of some states at higher and lower levels (i.e., the extremes) and the evolution of others going from lower to higher levels was observed. Roughly speaking, although the vast majority of web portals of Brazilian states, the empirical objects of this study, contribute to the transparency of the vaccination against COVID-19, there are states the portal of which, for being at opaque, low, or intermediary levels, seem to exist more due to a dominant technological imperative and less to favor the transparency of government actions.

Even identifying a satisfactory condition in a representative portion of the investigated entities, there was a lack of information on the vaccination process, and several clicks were necessary to obtain the information, often pulverized over panels, epidemiological bulletins, and news articles. Particularly, the sex criterion was one of the items met least, despite the National Operationalization Plan for the Vaccination against COVID-19 (Law No. 13979, 2020) defining that such a datum would be placed at the disposal of the general public. The fact that most of the information included on panels, epidemiological bulletins, and news articles were not concomitantly made available in open format also drew attention. Such findings also refer to the need for revising the analysis model itself.

The identification of a satisfactory condition in many Brazilian states does not mean that one is not before a long path of advances to be traversed. Even some states identified as having a high transparency level may still evolve, an effort that tends to be more significant in the states that occupy the lower levels (low and opaque). The advancement in the construction of transparency on the vaccination, not only relative to COVID-19 but also in the general sense of the vaccines, is important to inform the citizen and as an element of public policy management.

Hence, it was observed that this study contributes in theoretical and practical terms. The theoretical contribution is on account of an extremely incipient field when the focus is the transparency of the vaccination process. Although the OKBR index currently contemplates criteria related to vaccination, at the time the ITVC-BR was built and the data were collected, no indices 
that provided such analyses were found. Therefore, the study has a direct theoretical implication when it enables the development of an index that contributes to analyzing the transparency in the vaccination process against COVID-19. It is assumed that, in the future, the index may also be used for other types of vaccination, not just this one restricted to the pandemic context. Consequently, it contributes to bridging the gap in the literature, notably the national literature, captured through a survey on the Spell database.

Regarding the practical focus, this study already demonstrated contributions to the state during its development, given that, after closing each survey, the results were submitted to the respective communication sectors so they could check them and indicate any incoherence in the collection if it were the case and also verify points to be perfected in the transparency of the vaccination process. The practical contribution was also demonstrated through a diagnosis that public managers may use, besides the determination that transparency in the vaccination is only one of the many segments/views of transparency that merit attention, representing a vast and fertile field in terms of research.

Future studies are encouraged so they may provide continuity to the theme employed herein. Initially, studies that continue with the collections on state portals are glimpsed with the purpose of verifying possible evolutions in the transparency of the vaccination. Other studies may be carried out in metropolitan areas or municipalities. Parallel studies may be conducted to perfect the analysis model. From the perspective of Accounting Sciences, research may be performed focused on verifying how Public Accounting may contribute to perfecting the evincement of the results obtained with the implementation of public policies directed towards epidemiological/health issues.

\section{REFERENCES}

Decreto ${ }^{\circ}{ }^{\circ} 8.777$, de 11 de maio de 2016 (2016). Institui a Política de Dados Abertos do Poder Executivo Federal. Diário Oficial da União. Brasília, DF.

Lei Complementar n. ${ }^{\circ} 101$, de 04 de maio de 2000 (2000). Estabelece normas de finanças públicas voltadas para a responsabilidade na gestão fiscal e dá outras providências. Diário Oficial da União. Brasília, DF.

Lei Complementar n. ${ }^{\circ}$ 131, de 27 de maio de 2009 (2009). Acrescenta dispositivos à Lei Complementar n. ${ }^{\circ} 101$, de 4 de maio de 2000, que estabelece normas de finanças públicas voltadas para a responsabilidade na gestão fiscal e dá outras providências, a fím de determinar a disponibilização, em tempo real, de informações pormenorizadas sobre a execução orçamentária e financeira da União, dos Estados, do Distrito Federal e dos Municípios. Diário Oficial da União. Brasília, DF.

Lei $n^{\circ}{ }^{\circ} 12.527$, de 18 de novembro de 2011 (2011). Regula o acesso a informações previsto no inciso XXXIII do art. $5^{\circ}$, no inciso II do $\S 3^{\circ}$ do art. 37 e no $\S 2^{\circ}$ do art. 216 da Constituição Federal; altera a Lei n. ${ }^{\circ} 8.112$, de 11 de dezembro de 1990; revoga a Lei n. ${ }^{\circ} 11.111$, de 5 de maio de 2005, e dispositivos da Lei n. ${ }^{\circ} 8.159$, de 8 de janeiro de 1991; e dá outras providências. Diário Oficial da União. Brasília, DF.

Lei $n^{\circ}$ 13.979, de 06 de fevereiro de 2020 (2020). Dispõe sobre as medidas para enfrentamento da emergência de saúde pública de importância internacional decorrente do coronavírus responsável pelo surto de 2019. Diário Oficial da União. Brasília, DF. 
Loureiro, M. R., Teixeira, M. A. C., \& Prado, O. (2008). Construção de instituições democráticas no Brasil contemporâneo: transparência das contas públicas. Organizações \& Sociedade, 15(47), 107-119.

Machado, L. N. et al. (2020). Restrições ao direito de acesso à informação em contextos emergenciais: análise dos efeitos da Covid-19 nos governos subnacionais. Revista da CGU, 12(22), 246-259.

Michener, G., Contreras, E., \& Niskier, I. (2018). Da opacidade à transparência? avaliando a lei de acesso à informação no Brasil cinco anos depois. Revista de Administração Pública, 52(4), 610-629.

Open Knowledge Brasil. (2020). Índice de Transparência da Covid-19: nota metodológica. $\begin{array}{lllll}\text { Recuperado em } 02 & \text { maio, de }\end{array}$ https://transparenciacovid19.ok.org.br/files/Nota_Metodologica_Transparencia_da_Covid19_2.0.pdf

Pinho, J. A. G., \& Sacramento, A. R. S. (2009). Accountability: já podemos traduzi-la para o português? Revista de Administração Pública, 43(6), 1343-1368.

Pinho, J. A. G. et al. (2020). Transparência governamental em capitais dos estados no Brasil nas contratações emergenciais para o combate da Covid-19. Revista da CGU, 12(22), 260-274.

Portaria GM/MS n. ${ }^{\circ}$ 69, de 14 de janeiro de 2021 (2021). Institui a obrigatoriedade de registro de aplicação de vacinas contra a Covid-19 nos sistemas de informação do Ministério da Saúde. Diário Oficial da União. Brasília, DF.

Raupp, F. M., \& Pinho, J. A. G. (2020). Precisamos evoluir em transparência? - uma análise dos estados brasileiros na divulgação de informações sobre a Covid-19. Gestão e Sociedade, 14(39), 3725-3739.

Raupp, F. M., \& Pinho, J. A. G. (2021). Websites dos Poderes Executivos Estaduais e as Contratações Emergenciais em Meio à Pandemia da Covid-19: Há Tecnologia, mas Falta Transparência. Revista Gestão Organizacional, 14(1), 416-428.

Raupp, F. M., Sacramento, A. R. S., Santos, R. C. N., \& Pinho, J. A. G. de. (2021). Índice de transparência da vacinação contra a Covid-19 no Brasil: um estudo à luz da realidade empírica das capitais brasileiras. Teoria e Prática em Administração, 11(especial em saúde), 1-16.

Sacramento, A. R. S., \& Pinho, J. A. G. de. (2016). O processo de implementação da answerability no Brasil contemporâneo. Revista de Administração Pública, 50(2), 193-213.

Santos, J. G. D., \& Mota, F. P. B. (2020). A transparência governamental em tempos de Covid19: reflexões do quadro brasileiro. Gestão e Sociedade, 14(39), 3716-3724.

Schedler, A. (1999). Conceptualizing accountability. In A. Schedler, L. Diamond, \& M. F. Plattner (Eds). The self-restraing state: power and accountability in new democracies. Boulder and London: Lynne Rienner Publishers, 13-28. 
Zuccolotto, R., Teixeira, M. A. C., \& Riccio, E. L. (2015). Transparência: reposicionando o debate. Revista Contemporânea de Contabilidade, 12(25), 137-158. 